\title{
Generational Succession of DL-Alanine Dodecylester HCl-Induced Resistance to Blast Disease in Rice Plants
}

\author{
Yutaka Arimoto*, Yasuo Homma*, Reiichi Yoshino** \\ and Shiro SAITO***
}

\begin{abstract}
The outbreak of leaf and panicle blast caused by Pyricularia oryzae decreased to $25 \%$ (in greenhouse) and $50 \%$ (in paddy field) on rice plants by soaking seeds in DL-alanine dodecylester hydrochloride solution $(500 \mathrm{ppm})$. The second and the third generation of the rice plant retained this chemically ind uced resistance to the disease. The blast severity reduced to $39 \%$ in greenhouse test and $48 \%$ in field test (2nd generation), and $28 \%$ in greenhouse test (3rd generation). When the chemical treatment was repeated on alternate generations of the rice seeds, the induced protection effect of DL-alanine dodecylester hydrochloride reached at high levels of $75 \%$ (original), $61 \%$ (2nd generation), $87 \%$ (3rd generation) and $97 \%$ (4th generation) of blast-preventive values. On the rice plant whose blast resistance was chemically induced, conidia of $P$. oryzae germinated and formed appressoria, and then its hyphae penetrated into the host tissues. However, the invading hyphae were restrained in epidermal cells and adjoining cells without subsequent penetration.
\end{abstract}

(Received October 22, 1990)

Key words: DL-alanine dodecylester hydrochloride, chemically-induced resistance, Pyricularia oryzae.

\section{INTRODUCTION}

It is known that resistance of plants to diseases is induced by double inoculation of viral pathogens ${ }^{7}$. Initial inoculation with avirulent strains of Phytophthora infestans prevented potato from tuber rot disease caused by subsequent inoculation with sporangia of virulent strains of the pathogen ${ }^{8}$. Susceptible cucumbers to Colletotrichum lagenarium race 1 was systemically protected from the disease by prior inoculation with the pathogen ${ }^{6}$. Ishiba et al. demonstrated that cucumber was protected from $C$. lagenarium by root soaking in a suspension of extract of Fusarium oxysporum ${ }^{5}$, indicating that the pathogen does not participate in the resistance induction to plants, and that the disease resistance can be induced by chemicals.

We found that the blast lesions caused by Pyricularia oryzae were less numbers on the seedlings from seeds soaked in amino acid derivative solutions ${ }^{1)}$. The best protection was obtained using DL-alanine dodecylester hydrochloride.

* RIKEN (The Institute of Physical and Chemical Research), Hirosawa, Wako, Saitama 351-01, Japan 理化学研究所

** Agricultural Research Center, Yatabe-cho, Tsukuba, Ibaraki 305, Japan＼cjkstart農業研究センター

*** Tochigi Prefectural Agricultural Experimental Station, Kawaraya-cho, Utsunomiya, Tochigi 320, Japan＼cjkstart栃木県農業試験場 


\section{MATERIALS AND METHODS}

Preparation of seedlings. Rice seeds (cultivar: Jukkoku, Nihonbare and Koshihikari) were soaked in $500 \mathrm{ppm}$ DL-alanine dodecylester hydrochloride (1-dodecyloxycarbonyl ethylammonium chloride) solution (treatment: $\mathrm{T}$ ) or in distilled water (check: C) and incubated at $30^{\circ} \mathrm{C}$ for 3 days $^{1)}$. After rinsing with water, both the chemically treated and water-soaked seeds were sown and cultivated in a greenhouse or paddy field until harvest to obtain the second generation seeds. The second generation seeds harvested from the T-seedlings were soaked again either in $500 \mathrm{ppm}$ DL-alanine dodecylester hydrochloride (T-T) or distilled water (T-C) to prepare T-T-seedlings and T-C-seedlings.

These procedures were repeated for preparing the $3 \mathrm{rd}$ (T-T-T, T-T-C, T-C-T and T-C-C) and 4th (T-C-T-T, T-C-T-C- T-C-C-T and T-C-C-C) generation seedlings as shown in Fig. 1.

Greenhouse test. At the 4.5-leaf stage, these seedlings (50 seedlings per treatment) were inoculated with spore suspension $\left(4 \times 10^{4}\right.$ spore $\left./ \mathrm{ml}\right)$ of rice blast fungus, Pyricularia oryzae (isolate P2) by the method of Homma et al. ${ }^{4}$, and incubated in a moist chamber (Temp. $25^{\circ} \mathrm{C}$, R.H. $100 \%$ ) for 4 days. The number of lesions on the fifth leaf of the T-seedlings grown from chemically treated seeds was compared with that of C-seedlings from water-soaked seeds ${ }^{3)}$.

At the 7-leaf stage, the leaf sheaths of both $\mathrm{T}$ - and $\mathrm{C}$-seedlings grown in a greenhouse were stripped, and then a spore suspension of $P$. oryzae was inoculated on the inner surface of them. The inoculated leaf sheaths were incubated in a moist chamber. On 100 spores for each treatment, the spore germination, appressorial formation, appressorial penetration and elongation of hyphae invading into the tissue of the $\mathrm{T}$ - and $\mathrm{C}$-seedlings were observed through a light microscope 2 and 4 days after inoculation.

Field test. Both the chemically treated (T, T-C) and water-soaked (C, C-C) seedlings were planted in a paddy field, and then cultivated without application of any chemicals to control the rice blast. At harvest time, about 200 panicles in each treatment were used for observation, and the damage by the panicle blast on the plants ( $\mathrm{T}$ - and $\mathrm{T}-\mathrm{C}$-plant) grown from chemically treated seeds was compared with that on the plants (C-and C-C-plant) grown from water-soaked seeds. These experiments were repeated 3 times on three cultivars, Jukkoku, Nihonbare and Koshihikari.

\section{RESULTS AND DISCUSSION}

As shown in Fig. 1, on T-seedlings grown in the greenhouse, the number of rice blast lesions was less than that on the C-seedlings with a preventive value of $75 \%$. Several experiments were conducted for the confirmation of this phenomenon, and preventive values of $69,77,92$, 98 and $98 \%$ were obtained. This chemically induced resistance in the T-seedlings was effective without decrease in the 2 nd $(\mathrm{T}-\mathrm{C})$ and the $3 \mathrm{rd}(\mathrm{T}-\mathrm{C}-\mathrm{C})$ generations of plants, and preventive values were $61 \%$ (T-C) and $72 \%$ (T-C-C). On the other hand, the fourth generation seedling (T-C-C-C) from seeds whose original-generation seed was treated with the chemical did not show the protective effect against rice blast.

When rice seeds in each generation were treated with the chemical, the preventive value of $75 \%$ on the original generation seedlings (T) became $35 \%$ in the 2 nd (T-T) and $28 \%$ in the 3rd (T-T-T) generation.

When rice seeds in alternate generations were treated with the chemical solution, the protective effect remained, without decrease, in all generations from the original to the 4th. These seedlings showed 75 (T), 61 (T-C), 87 (T-C-T), and 97\% (T-C-T-C) reduction in disease incidence respectivelty.

As shown in Table 1, the damage by panicle blast on T-plants in the paddy field was less 


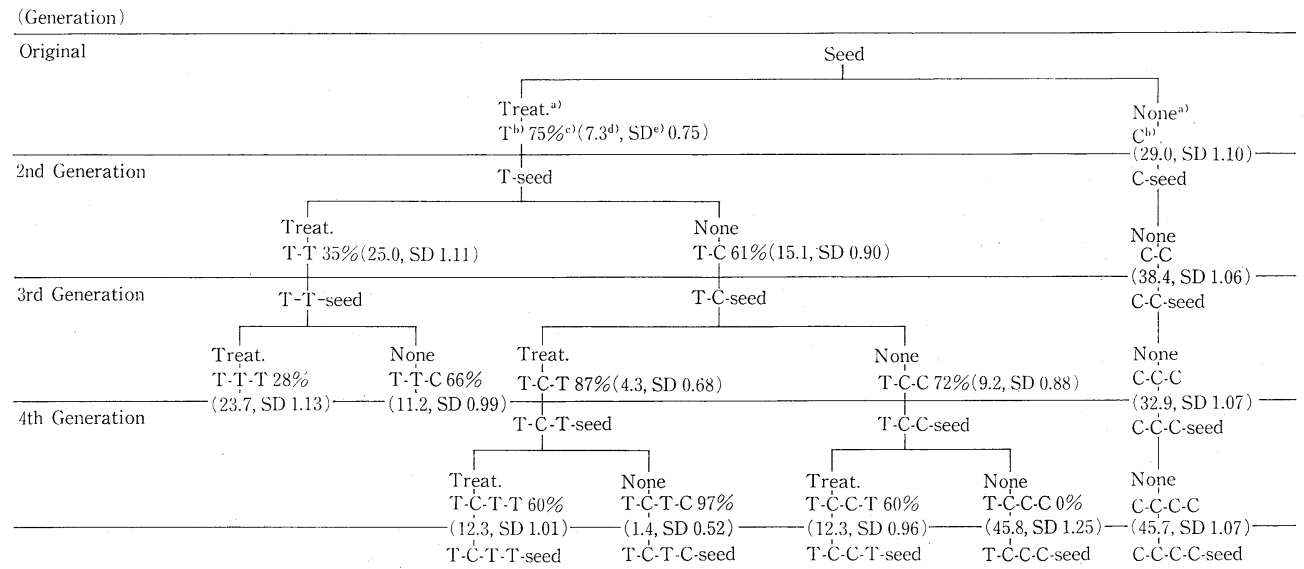

Fig. 1. Effect of seed soaking in DL-alanine dodecylester hydrochloride solution on blast disease of rice seedling (cv. Jukkoku) in greenhouse. At the 4.5-leaf stage, those seedlings (50 seedlings per treatment) were inoculated with spore suspension $\left(4 \times 10^{4} \mathrm{spore} / \mathrm{ml}\right)$ of Pyricularia oryzae (isolate P2), and incubated in a moist chamber (Temp. $25^{\circ} \mathrm{C}, \mathrm{R} . \mathrm{H}$. $100 \%$ ) for 4 days. a) rice seeds soaked in $500 \mathrm{ppm}$ of the chemical (Treat.) or in distilled water (None); b) seedlings from the seeds soaked in the chemical (T) or water (C); c) preventive value; d) number of rice blast lesions/leaf; e) standard error.

Table 1. Effect of seed soaking in DL-alanine dodecylester hydrochloride solution on panicle blast of rice in fields a)

\begin{tabular}{lccc}
\hline \multirow{2}{*}{ Generation } & \multicolumn{3}{c}{ Preventive value (\%) ${ }^{\mathrm{b})}$ on cultiver: } \\
\cline { 2 - 4 } & Jukkoku & Nihonbare & Koshihikari \\
\hline Original (T) & $31^{*}$ & $57^{* *}$ & 67 \\
Second (T-C) & $67^{*}$ & $57^{* *}$ & 43 \\
Check (C-C) & 0 & 0 & 0
\end{tabular}

a) Seedlings from the seeds soaked in the chemical (T, T-C) or water (C-C) were planted in a paddy field, and then cultivated without application of any chemicals to control the rice blast. At harvest time, about 200 panicles in each treatment were used for observation.

b) $*$, the statistical difference at $10 \%$ level. **, the statistical difference at $5 \%$ level.

Table 2. Effect of seed soaking in DL-alanine dodecylester hydrochloride solution on the growth stage of Pyricularia oryzae by rice sheath method a)

\begin{tabular}{lc}
\hline \hline Gowth stage & Inhibition (\%) \\
\hline Conidial germination & 0.0 \\
Appressorial formation & 0.7 \\
Appressorial penetration & 8.7 \\
Hyphal elongation in leaf sheath tissue & 98.2 \\
\hline
\end{tabular}

a) The inner surface of leaf sheaths of seedlings (7-leaf stage) from the seeds soaked in the chemical or water was inoculated with the spore suspension of $P$. oryzae. After incubation in the moist chamber at $25^{\circ} \mathrm{C}$ for 2 or 4 days, about 100 spores for each treatment were observed.

than that on C-plants with preventive values of 31,57 and $67 \%$. The chemically induced resistance of the $\mathrm{T}$-plants was persistent without decrease in the second (T-C) generation of the plant in the paddy field. The T-C-plants showed 57, 67 and 43\% reduction in disease incidence.

As shown in Table 2, while spore germination and appressorial formation were not inhibited 
on the T-seedlings, the invaded hyphae were restricted in the first penetrated epidermal cells or adjoining cells. No further growth of the invaded hyphae was observed, and small brown spots were formed on sheaths of the T-seedlings for 4 days after inoculation. On the other hand, on the C-seedlings from water-soaked seeds, there was no inhibition at any stages of the fungal growth.

The present experimental results indicate an interesting fact that the chemical induces resistance of rice plant against rice blast caused by $P$. oryzae, resulting in about $70 \%$ disease control, and the chemically induced resistance is persistent without decrease, until the third generation, although the mechanism of the resistance persistence is not clear. While the rice blast did not reduced on the first, second and third leaves of the seedlings from seeds soaked in the chemical solution, the disease severity reduced on the 4th leaf or later leaves of the same seedlings ${ }^{1)}$. Those three leaves, $1 \mathrm{st}, 2 \mathrm{nd}$ and $3 \mathrm{rd}$, had already differentiated in the rice seeds ${ }^{2}$, and proved that the chemical was unable to induce the resistance in the leaves which had been differentiated before the treatment. On the other hand, the resistance was induced not only in the 4th but also in flag leaves that differentiated after the treatment.

This phenomenon would suggest that the chemical induced the "resistance" in growing point cells of the rice plant, and the "resistance" was able to be persistent in the cells. Therefore, it is thought that the seeds which differentiated from the "resistant" cells also persist in the "resistance." However, more detailed studies will be needed to clarify the mechanisms of the resistance persistence.

\section{Literature cited}

1. Arimoto, Y., Homma, Y., Ohtsu, N. and Misato, T. (1976). Studies on chemically induced resistance of plants to diseases. 1. The effect of a soaking of rice seed in dodecyl DL-alaninate hydrochloride on seedling infection by Pyricularia oryzae. Ann. Phytopath. Soc. Japan 42: 397-400.

2. Cho, S. (1960). Embryo development. In Structure and function of rice plant (Matsuo, T. ed.). Nogyogijyutsukyokai, Tokyo. pp. 6-13 (in Japanese).

3. Homma, Y., Arimoto, Y. and Misato, T. (1981). Studies on the control of plant diseases by sodium bicarbonate formulation 1. Effects of emulsifiers and surfactants on the protective values of sodium bicarbonate. J. Pesticide Sci. 6: 145-153.

4. Homma, Y., Shida, T. and Misato, T. (1973). Studies on the control of plant diseases by amino acid derivatives (1) Effect of N-lauroyl-L-valine on rice blast. Ann. Phytopath. Soc. Japan 39: 9098.

5. Ishiba, C., Tani, T. and Murata, M. (1981). Protection of cucumber against anthracnose by a hypovirulent strain of Fusarium oxysporum f. sp. cucumerinum. Ann. Phytopath. Soc. Japan 47: 352-359.

6. Kuć, J., Shockley, G. and Kearney, K. (1975). Protection of cucumber against Colletotrichum lagenarium by Colletotrichum lagenarium. Physiol. Plant Pathology 7: 195-199.

7. McKinney, H.H. (1929). Mosaic disease in the Canary Islands, West Africa and Gibraltar. J. Agr. Res. 39: 557-578.

8. Müller, K.O., Meyer, G. and Klinkowski, M. (1949). Physiologisch-genetische Untersuchungen über die Resistanz der Kartoffel gegenüber, Phytophthora infestans. Naturwissenschaften 27: 765768 .

\section{和 文 摘 要}

有本 裕・本間保男・吉野嶺一・斎藤司朗：DL-alanine dodecylester $\mathrm{HCl}$ によりイネに誘導されたいるち 病抵抗性の世代継䊦

イネ種粐を DL-alanine dodecylester $\mathrm{HCl}$ 溶液 (500 ppm) 飞浸漬し栽培したイネでは, 葉いもち病だけで なく穂いもちの発生がそれぞれ約 75\%（温室）扣よび 50\% (阑場) も少なかった。これはいもら病に対す る抵抗性が誘導されたものと考光られた。化学的に誘導された抵抗性は世代を越兄て継続され，2 代目では $61 \%$ (温室) 特よび $52 \%$ (直場)，3 代目では $72 \%$ (温室) いもち病の発生が抑制された。種粐浸漬を 1 年物きに行うと,いもち病の抑制効果は高く保たれた。抵抗性が誘導されたイネに拉ける Pyricularia oryzae の胞子発芽拉よび付着器形成, 侵入は無処理イネでのそれらと同じであったが, 侵入菌糸は最初に到達した 表皮細胞内㧊よびそれに隣接した細胞内に封じ込められた。 